\title{
WestVirginiaUniversity
}

THE RESEARCH REPOSITORY @ WVU

Volume 31 | Issue 2

Article 5

February 1925

\section{Early Frontier Democracy in the First Kentucky Constitution}

E. Merton Coulter

University of Georgia

Follow this and additional works at: https://researchrepository.wvu.edu/wvlr

Part of the Constitutional Law Commons, and the State and Local Government Law Commons

\section{Recommended Citation}

E. M. Coulter, Early Frontier Democracy in the First Kentucky Constitution, 31 W. Va. L. Rev. (1925).

Available at: https://researchrepository.wvu.edu/wvlr/vol31/iss2/5

This Article is brought to you for free and open access by the WVU College of Law at The Research Repository @ WVU. It has been accepted for inclusion in West Virginia Law Review by an authorized editor of The Research Repository@WVU. For more information, please contact ian.harmon@mail.wvu.edu. 


\section{EARLY FRONTIER DEMOCRACY IN THE FIRST}

\section{KENTUCKY CONSTITUTION*}

\section{E. Merton Coulter**}

In her struggle for self-government, Kentucky was forced to pass through the tortuous course of no less than ten conventions, attended by almost as many racking disappointments. The first settlers had arrived on the eve of the Revolution and had tenaciously maintained themselves throughout the war with virtually no aid from Virginia, cut off as they were five hundred miles to the west. Finally succeeding over both British and Indians, they came out of the struggle with a feeling of confidence in themselves, with a spirit of independent initiative, and with little patience for control from any atuhority east of the mountains. ${ }^{2}$ There should be little wonder, then if these people in their constitutionmaking should spurn the thought of being copyists of anybody. F'urthermore, many people had come to Kentucky directly after the Revolution and had soon become discontented over a situation where a few people had secured control of a large part of the best land. Discontent became widespread. Two years after Paine's Public Good had been written it reached this region and had the baneful effect, through its claims that Virginia did not own the Western country, of upsetting those who possessed the land, and of raising false hopes in the landless that they might disregard the Virginia grants and lay hold on the region. Two trouble-makers who appeared in Lexington and Louisville in 1784, advocating this procedure, were arrested and heavily fined. ${ }^{2}$ The spirit of radicalism and distrust had thus made its appearance; and a cleft in Kentucky society and thought developed between those who had much and those who had little or nothing. That

- This article is republished, with permisslon, from the Pourical Scrance QuARTERLY. Vol XXXIX, No. 4, December, 1924, published by the Academy of Political Science, Columbia University, New York City.

* Professor of Elistory, University of Georgla, Athens, Ga .

1 Little blame can attach to Virginia for not glving aid, as she was fully occupled in the east. George Rogers Clark's expedition into the Northwest afoorded Iittle protection to Kentucky, where the bellef prevalled that it would have tho opposito effect. Hence it was that Clark got no recrults west of the mountains.

2 W. E. ConNeliey and E. M. Coulter, History on Kentucky (Chicago 1922), Vol. 1, p. 224 . 
this should be reflected in constitution-making should, therefore not cause surprise.

The Kentucky leaders, who were naturally the great property holders and, therefore, conservative men, early tried to guide the thoughts of the people along tried and conservative lines. As the course of the conventions extended over a period of a half dozen years, there was ample time for study and discussion of the principles that should go into a constitution, should the District be so fortunate as to secure separation from Virginia and admission into the Union. It was generally expected that the fourth convention, which was to meet in September, 1786, would frame the constitution. In pursuance of this idea, Caleb Wallace wrote James Madison in August (1786) for his views on the sort of document Kentucky should have. Madison in his reply recited at great length the old and generally-accepted constitutional principles of the times. ${ }^{3}$

Due to unforeseen circumstances the convention was never able to secure a quorum and so went out of existence without having accomplished anything. Two years passed with the holding unsuccessfully of the fifth convention to secure separation from Virginia, and then the sixth met in July, 1788, which it was hoped, would sever the ties with the mother state and make a constitution. By this time crafty James Wilkinson had cunningly wormed himself into the favor of Kentuckians, as well as of the Spaniards in New Orleans, and was now a member of the convention. His plans contemplated a separation from Virginia, the making of a constitution, but not the entry of Kentucky into the Union." Enough was known of his intriguing with the Spaniards to prevent the drawing-up at this time of a form of government; but in the seventh convention, which met in the following November, he had the partial sympathy of a disappointed, long-suffering and disgruntled people, and actively aided by John Brown, also a member, he led another bold attempt to frame a constitution. Brown formulated one after consultation with Jefferson and Madison and had it ready to present to the convention; but Wilkinson, too bold in unfolding his beautiful Spanish scheme, overshot the mark, and so scared the delegates that it was voted to adjourn without further action. ${ }^{5}$ Finally in July, 1790, after eight attempts, a ninth convention was held, which successfully catching

3 The WaIring of Jamieg Madison, edited by Gathlazd Hunt (New Tork, 1900-1910), Vol. II, pp. 166-177.

- Connelifir and Coulter, history of Kentucky, Vol. I, pp. 252-259.

E Told., pp. 260-268. 
the will-o'-the-wisp of separation from Virginia, ordered a tenth convention to meet two years later with the definite and only purpose of making a framework of government.

Throughout the period of these nine conventions the thoughts of the people had been somewhat diverted from constitutional principles in their attempts to secure separation from Virginia and in listening too attentively to Spanish intrigues. There was, however, one group of people who refused to be disturbed.. The Danville Political Club, having among its members some of the outstanding leaders of the District, met regularly at Danville throughout the year, 1787, and threshed out many constitutional questions. $^{6}$ As members of this club were later delegates to the convention which framed the constitution, and as their decisions undoubtedly got out among the people and were discussed, this organization considerably influenced the first constitution. Its membership naturally gave it a character conservative as far as frontiersmen were concerned, but liberal in comparison with eastern thought and traditions. Debates were long and heated, sometimes lasting beyond midnight, disturbing the peace of the travelers stopping at the tavern and of the less slumberous townsmen. That these debaters were doing their own thinking was set forth in their various decisions. Among the early questions they settled was that representation in the assembly should be based on population and not on counties as Virginia had it. ${ }^{7}$ Surrounded by many dangers that made life uncertain, these leaders of frontier thought debated the question of legal hazards that beset the citizen in the eastern states, and came to the conclusion that the death penalty ought to be inflicted for no other crimes than murder and treason.

But these men were yet conservative, far more so than many of their less fortunate and more clamorous neighbors. There should be no annaul elections which the rabble wanted; once in two years was often enough. Furthermore, the fact that a man possessed simply freedom was not enough to make him a voter. The legislature should have two branches instead of one, for in that fashion the snap judgments of the mob in the lower house could be nullified; and to make it more certain that the mob should not control the second branch, it was debated whether the latter should not be chosen by electors selected for that purpose. ${ }^{8}$ This club

It was organized in December 1786 , and was maintained actlvely durlng the following year. It lingered until 1790. THOMas SPEed, The PoltTical Crub. Danville, Kentucky, 1786-1790 (Filson Club Publication, No. 9, Loulsville, 1894).

T Ibid., p. 113. All the minutes extant may be found In this volume.

s The decision is not known as there is a gap in the minutes at this point. 
hit upon a plan which came later to be one of the surest stops to unregulated democracy, by holding that a judge should allow the constitution to govern his decision, when a law conflicted with it. ${ }^{9}$ To gather together all of its various decisions and ideas this club appointed a committee to draw up a "Bill of Rights and Constitution or form of government which they shall think agreeable to and convenient with the local situation of the District"; but no copy of such a document is preserved, if one were ever formulated. It was during the active period of this debating club's existence that the Federal Constitution was made; and as soon as a copy of it could be secured, these Danville debaters proceeded for four months to dissect it to the minutest detail and to find much with which they disagreed. When they had finished, every clause in the document was labeled with such expressions as "amended," "rejected," "disagreed to," "expunged," "stuck out," and "agreed." One of their first criticisms was to note the lack of a bill of rights. Also they could see no good in having a vice-president; so they abolished the office. They would preserve the constitution from legislative as well as executive infractions by requiring the president to withhold his signature from all bills without "the advice and consent" of the "Executive Council [cabinet] and Judges of the Supreme Court." They would have the senators to sit for only three years and be ineligible for a second term until an equal period of time should have elapsed, and the president should not be re-elected for four years after the end of any term. ${ }^{10}$ The general dislike of the Danville Club for the Federal Constitution seems to have been typical of the District, as only three of the fourteen Kentucky delegates in the Virginia ratification convention voted for it. ${ }^{11}$

With the time for the final convention drawing near, discussion became more widespread and intense; and it became the chief diversion of the District to play at making constitutions. Perhaps no other American community ever so completely gave itself over to thoughts and arguments on constitutional principles. It was felt that now was the sublime moment of all time, when every person was a monarch, when he was sovereign and it was his to give and his to withhold. Man was virtually in a state of nature; he was about to create a fabric of government out of a void. These rampant-visioned ones claimed that they were not beholden in the

- The flrst instance in which a judge so decided in an American state was in North Caroline in this same year. 1 MARTIN's REPORTB, 48.

10 Speed, Political Club, pp. 144-148.

11 ConNeliey aND COULTER, History of KeNtucky, Vol. I, pp. 252-254. 
slightest to Virginia or the Federal Government. ${ }^{22}$ They were now about to make a constitution untrammeled by colonial precedents and uninfluenced by the exigencies of war, as had been the case in constitution-making with all the states east of the mountains. An enthusiastic Kentuckian exclaimed, "What would not some in some of the eastern states give, to be in our situation, that is, to have the privilege of beginning a new government."13 It was, indeed, a solemn occasion to crystallize out the institutions by which future generations were to be bound, and according to one who would not be cheated, "every cast and denomination of men amongst us, are entitled to a representation in forming a constitution by which they will be equally bound." "14 However, another roter, styling himself "Rob the Thrasher," thought the occasion should not inspire so much awe; the constitution could always be changed. The living did what they pleased; the dead could not prevent it. ${ }^{15}$ The great mass of the people was thoroughly aroused: they should act quickly and certainly or the victory would be plucked from them by designing men. There was a distinct move on the part of the more democratically and more radically minded to assume control from the natural leaders of the District and make a constitution after their own liking.

The Kentucky Gazette, which had been started a few years before, was open to all who eared to express their views, and for two years before the convention met, its columns were filled with communications from the high and the low. There was a deepseated prejudice against the educated leaders, who were attempting to direct affairs. "I never was a friend of larned men," said a frontiersman, "for I see it is those sort of follss who always no how to butter thare own bred and care not for orthers." "10 They were designing men who would control the government for their own aggrandizement, for this was the history of government in the past. One outspoken representative of the common people said, "I have long been of opinion that the business of government is a cheat; and that he is really a fool who has no hand in it. . . . The great men know as I have before hinted, that the art of government is nothing but playing the rogue by authority of law." $\mathrm{He}$ called on all who were "for the good of the country" to "keep up the ery against Judges, Lawyers, Generals, Colonels, and all

\footnotetext{
12 KgNTUCKY GAZETTE, passim, 1791, 1792.

1s Ibid, Jan. 7, 1792. By "H. S. B. M."

1 KENTUCEY GazeTte, Oct. 8, 1781.

15 Ioid., Dec. 17.

16 Ibid., Nov. 26.
} 
designing men." yers, who made laws so obscure that honest men could not understand them, and hence secured business for themselves. A Kentuckian writing over the name of "Salamander" declared that "the fewer Lawyers and Pickpockets there are in a country, the better chance honest people have to keep their own." 18 They should be excluded from the convention. ${ }^{19}$ Government was very simple, so simple that anyone could understand it, if designing men could be kept from obscuring it. A woman made bold under the name of "The Medler" to inquire what there was "to hinder any man of common sense that reads, thinks and talks, to make himself acquainted with the rights of mankind and the act of government." Government should not only be made simple, but it should be collected in "country produce" with the exception of a tax on unused lands. ${ }^{21}$ If the rich, the wise and the great would not take part in such an arrangement, then let them go, and the people might rejoice at a good riddance. The constitution rather than the legislature should fix salaries. ${ }^{22}$ Many of the people were getting their inspiration from Paine's Rights of Man, extracts from which were published in the Kentucky Gazette at various times. ${ }^{23}$

Aside from the general principles of government, various parts of the specific framework of the constitution that should be made were widely discussed. The Kentucky Gazette published during the latter part of 1791 a constitution, which called for election periods of five days during which no person could be civilly restrained, for the emancipation of slaves at a date to be fixed, and for the distribution of the constitution among the voters at certain intervals. ${ }^{24}$ These subjects and many others, the people had set themselves to diseussing. Much was said for and against a bill of rights; ${ }^{25}$ but the subject that drew the most heated argument was the number of branches the legislature should have. This question was made the touchstone for radicals and conservatives. Anyone advocating two houses had evil designs on the liberties of the people, for would not such an arrangement set up invidious distinctions with senators and commoners. One house would block the efforts of the other, and the quarrel would spread

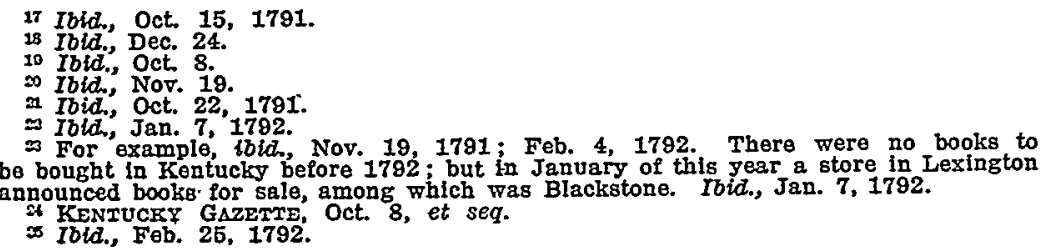


over the state, arraying one class against another. Furthermore, it would be an additional expense. ${ }^{28}$ If two houses be better than one, a logician arose to see the matter through and to conclude that " 1000 must be a thousand times better." inaudible was going up against slavery. This was a thrust at the landed aristocracy, and was largely the product of religious societies, chief among which were the Baptists at this time. ${ }^{28}$

Despite all the heated arguments that had taken place, what assurance could the people have that the constitutional convention would obey their wishes? How could they transfer their sovereignty to that body and not run the risk of being cheated out of their liberties? To serve this purpose, a system of county committees was devised, which would act as the safeguard of the poor and the honest against the rich and the designing. They would direct the opinions and the desires of the people and give them uniformity and make them articulate. They would determine what should go into the constitution, would instruct the conrention as the work proceeded, and when the finished document should be submitted to the people for ratification, they would be used to express the popular will, for otherwise the masses would "be in a great measure dumb upon this occasion," or nothing could "be heard but a confused uproar." 29 In fact these committees with slight changes in organization should be made permanent and should have a right to veto bills passed by the assembly. ${ }^{30}$ In order to secure uniformity of opinion for all of the counties, general conventions should be held where all would be represented. Such a meeting took place in Harrodsburg in November, 1791..$^{31}$

The method of organizing these committees and the way in which they should function were first suggested and put into operation by Bourbon County. Each militia company should choose a committee which in turn should select two representatives to meet with like representatives from other companies at the county seat, there to select the county candidates for the convention and formulate instructions for them. The ticket should be leferred back to the militia companies for their approval. By designating the candidates early, it was hoped that election disordors would be prevented. ${ }^{32}$ The committee in this county and the one

Ibia., Oct. 15, 22, passim, 1781.

st Ibid., Dec. 24. Kentuck: (Filson Club Publlcation, No. 6, Loulsvillo, 1889, pp. 22-230).

zo KeNTucky Gazetre, Oct. 15, 1701. Bourbon County Committeo's Addro3B to the Peoplo. Also see ibid., Oct. 8, 22. Nov. 26.

so Ibid., Nov. 19 . This was an early idea in Amorlca, of the roperendum.

31 Ibid., Oct. 8, 1791 , for the call; Dec. 24 for the meeting.

so Ibid., Oct. 16, 1781. 
in Fayette developed considerable strength and influence. The former county early selected its candidates and formulated their instructions. The legislature should be composed of only one house; voting should be by ballot; and immoral men should be excluded from places of trust and power. It decided that no laws of the English or of any other people should be adopted by the state, but instead, "that a simple and concise code of laws be framed, adapted to the weakest capacity; which we humbly conceive, will happily supercede the necessity of attorneys, pleading in the state." ${ }^{\prime 33}$ Permanent committees were to be elected by each county to watch over the interests of the people. In forming them, there were to be three "registers" elected from each district in the county, who should assemble all the freemen of the district to consult together on the common good; and at least once a year all the "registers" of the county should meet together to consider the general welfare, to instruct their representatives, and to apply for a redress of grievances. ${ }^{34}$ Important provisions for a constitution were drawn up in a meeting in November, at the Sinking Springs Meeting House near Paris. ${ }^{35}$ The Fayette County committee, later in starting, was busily holding meetings to formulate its instructions, only a month before the constitutional convention was to assemble. It invited the "religious societies" and all militia companies not yet represented to send delegates, and promised that its sittings would soon be thrown open to the public. $^{36}$

In Madison, Mercer and Mason counties there were strong movements to organize committees. In Woodford County, when it seemed that a committee was about to be formed, a magistrate threatened bodily harm to anyone attempting it. ${ }^{37}$ In fact this movement to organize committees soon came to be bitterly condemned and strongly opposed by the conservative leaders. They came out against this secret picking of candidates and declared that the committees in their instructions were attempting to usurp the very duties the convention was to be elected to perform. ${ }^{38}$ "Felte Firebrand" poured forth his wrath in the columns of the Gazette ;" and "A. B. C." had no patience with the "chimneycorner instructions" of these county committees. If the constitution was to be made by the people's representatives, let their

$\$$ Ibid.

3 KLENTUCKY GAZRTIE, Feb. 11, 1792.

$5 s$ Ibid.

cs Ibid., March 3.

IT Ibid., Deo. 24, 1701

33 Ibid., Oct 15, Nov. 17, 1791

so Ibid., Nov. 12, 1791 . 
deliberations be free, he maintained, "or, if a constitution is to be framed by the people, let them assemble for the purpose in some extensive plain, where each individual can hear and be heard in turn, and where a general vote may determine the public will." "I would ask," he continued, "what may be the consequence, if people of the several counties, each equally confident of being in the right, should give contradictory instructions to their respective representatives? Will not obstinate contentions in the conventions be the result, displeasing to each of the counties, and inconsistent with itself? ? $^{40}$ The committee supporters declared that only those who would deprive the people of their rights were against the committee system. ${ }^{11}$

On April 2, 1792, the convention met, elected by manhood suffrage, ${ }^{42}$ and sixteen days later finished its labors and adjourned. In a little more than two weeks it had given the people a government, over which they had been contending for the preceeding two years. The convention was surprisingly free from strife and acrimonious discussions. In fact all of this had taken place during the months preceding, so that when the body met, it had only to crystallize the opinions already expressed and translate them into fundamental law. The Kentucky Gazette made not a reference to the convention while it was in session, and the first evidence it gave of anything having happened was to print ten days after its adjournment a part of the constitution, and on May 12 to advertise copies of the document for sale.

The constitution was preeminently a compromise, a strange mixture of progressive democracy and staid conservatism. The masses had had their fling before the convention; the conservatives had their day in the convention. The former would throw precedents and other people's experiences to the winds; the latter would stand by the old moorings. George Nicholas, fresh from Virginia, had more to do with the conservative shaping of the document than any other person. He had just made a detailed study of such subjects as "Government," "Resolutions Regarding Form of Gorernment for Kentucky," "Land Tax," "Loan Office," "Checks and Division of Power," "Senate," "House of Representatives," "Governor," "Appointment to Office," "Suffrage," "Bill of Rights," "Courts," and "Slaves."

\footnotetext{
is Ibid., Oct. 8.

4 Ibla., Dec. 24.

1. Iold., Nov. 5.

is Nicholas manuscripts in the Durrett Collection in the Univeralty of Ohicago Library.
} 
resigned from the convention five days after it met and was triumphantly re-elected and returned three days later. ${ }^{44}$

Yet frontier democracy forced its way in. All free male citizens twenty-one years of age were given the right to vote. ${ }^{45}$ Representation was based on population rather than on territorial units as in Virginia; and it was declared "That the civil rights, privileges, or capacities of any citizen shall in no way be diminished or enlarged on account of his religion." Elections for representatives were to be held annually. These principles constituted democracy far in advance of most of the East.

But Democracy did not go unbridled. Here is seen an unusual admixture of sentiment for popular sovereignty and a fear of too much of it. In this new community, scarcely a dozen years out of the stockades, the cry of aristocracy had already been heard and agitators had stirred up a class hatred louder than it was dangerous. So it was, then, that the more substantial element was led to guard against a condition where unreasoning popular passion might wreck the social and economic order. The governor, the senators, and the judges, as well as a host of minor officers, were removed from direct election by the people. A board of electors, equal in number to the representatives, selected both senators and governor, while the latter appointed the judges as well as numerous other officers. The popular desire for a legislature of one house was disregarded. The conservative hand of the Danville debaters was seen in this, so also in the electoral system for senators and governor, as well as in the absence of a lieutenant-governor. The movement that had been started against slavery, the footstool of the aristocrats, met complete defeat. It was on this question that the bitterest fight took place, with all he preacher members, six in number, lined up against the institution. ${ }^{46}$ But instead of winning their battle, they led the convention to rivet slavery tight upon the state and to prohibit forever the sitting of a minister in the legislature.7 The constitution was not submitted to the people for ratification.

\footnotetext{
" "Mfinutes of the Convention of 1782" (MS.) in Durrett Collection. Nicholas was on the committee to draft the constitution. The other members were Cuthbert Harrison, Benjamin Sebastian, Isaac Shelby, Thomas Kennedy, Thomas Lrowls, Caleb Wallace, James Garrard, Thomas Waring and Alexander 's. Bullitt. Ibid, p. 20.

is In Virginla a property quallication was required. In the act of the Virginia legislature incorporating Lexington in 1787, a property qualification of twenty-five pounds pas put upon the right to vote. J. R. ROBERTson, PEIrTIONs of THE EARIY INHABITANTS OF KENTUCKY TO TEE GENERAI ASSENBLY OF VIRGINIA, 1769 to 1782 (Flison Club Publication, No. 27. Louisville, 1914), p. 106.

16. "Minutes of the Convention of 1792," p. 23 .

4 The leglslature was forbldden to free any siaves without the master's congent and without compensation. It could not prohibit the bringing of slaves into the state as indivldual property, but it could exclude them as merchandise. It might also pass lavs requirling owiners of slaves to treat them with humanity and to provide them with necessary food and clothing and to refrain from injuring them in life and limb. Article IX.
} 
There can be no doubt that the conservative element, with its skillful leaders, won the day in the convention, and produced a constitution far removed from the rampant democracy so evidently desired by the masses of the people. As soon as its contents were known it was set upon by the discontented and the disappointed and the fight grew more bitter until a new constitution was made seven years later. In both diction and in content, it showed close kinship to the Federal Constitution. A contemporary critic declared that "in most parts" it was "an exact copy." "48 Washington said that it might be "considered as particularly interesting since besides the immediate benefits resulting from it, it is another auspicious demonstration of the facility and success with which an enlightened people is capable of providing for their own safety and happiness." ${ }^{40}$ The people won a partial victory and to that extent frontier democracy was triumphant where it failed the incentive was ever present to continue the fight. The subsequent history of the state gave eloquent proof that the edge of frontier democracy was long to remain sharp and keen.

23 mentuchy Gazetrp. Nov, 17, 1792. Also see Prochedings of the American FIIBTORICAL Assoctation, Vol. V, p. 361.

10 A Compilation of the Messages and Papers of the Presidents, 1798-1897, edited by James D. Richardion, Vol. I, p. 132. 